$\mathbb{T}$ periodica polytechnica

\author{
Social and Management Sciences \\ $19 / 2(2011) 75+85$ \\ doi: 10.3311/pp.so.2011-2.04 \\ web: http://www.pp.bme.hu/so \\ (c) Periodica Polytechnica 2011
}

RESEARCH ARTICLE

\section{Administrative systems and reforms across the European Union - towards sustainability?}

\author{
György Ádám Horváth
}

Received 2011-06-07

\begin{abstract}
This paper presents an overview of the particularities of the administrative systems across the European Union. With more and more countries becoming members of the Union, legal and administrative harmonisation becomes more important than ever. Both internal and external aspects may trigger changes, whose scale will be dependent of many factors. It must be realised that administration in this case does not just mean dealing with bureaucratic red tape and obtaining documents, but rather it largely refers to the communal services provided by administrative units to their citizens. These will naturally have an effect on the socio-economic status of the served area, but lest one forget that there is also an environmental aspect to it. This paper will present an overview of the key aspects of administrative divisions across the European Union, and highlight the most important recent changes in the structure, and considering their sustainability aspects too.
\end{abstract}

\section{Keywords}

European administrative systems $\cdot$ administrative reform $\cdot$ regions $\cdot$ local administration $\cdot$ sustainable development

\section{Acknowledgement}

This work is connected to the scientific program of the "Development of quality-oriented and harmonized $R+D+I$ strategy and functional model at BME" project. This project is supported by the New Hungary Development Plan (Project ID: TÁMOP4.2.1/B-09/1/KMR-2010-0002)

\section{György Ádám Horváth}

Department of Environmental Economics, BME, 1117-Budapest, Magyar tudósok krt. 2. Q-A 235, Hungary

e-mail: george@eik.bme.hu

\section{Introduction}

Some 54 years have passed since the foundation of the predecessor European Union. Its course of transformation has been described by some as one from fund to empire. In stark contrast to its original six members, currently 27 states pertain to this Union, and it can be expected that the number of states will increase once again in the near future.

In varietate concordia, or "United in Diversity", this is the motto of the European Union. And truly, successive expansions have made sure that there is no shortage in diversity. Indeed, the Union has to tackle two great problems: unification on one side, and the preservation of diversity on the other. Europe's strength comes from diversity, although paradoxically this is the greatest threat to its efficient functioning. Efficient, in this case not referring to administrative efficiency, being speedy and sufficient, nor to economic efficiency, being a simple synonym of cheap, but rather efficient in serving sustainable development.

In the struggle towards sustainable development, some states are able to show significant achievements, whilst others have been less successful. We can name a number of reasons of success, both from the side of the economy and society. This paper intends to examine this topic from the aspect of administrative systems.

The paper will introduce the various administrative systems in Europe, and will attempt to highlight the similarities and shine some light on the differences. The paper will introduce NUTS, -Nomenclature d'Unités Territoriales Statistiques - an essential achievement in regional and spatial development, which could also serve as an outstanding guideline to any future administrative reform. The paper will also address lower level units of NUTS, containing the subdivisions of local administration.

The paper will discuss the most important administrative changes during the last few decades, focusing on the reasons and the experiences. The paper will attempt to evaluate currently existing administrative systems in terms of sustainability, explaining which ones would serve sustainable development the most, and what improvements could be made.

Firstly, though, let's sum up the main tasks public administrations need to take on. 


\section{Key functions of administration}

From an average citizen's view, public administration may only be apparent, when one obtains a new ID-card or a Driver's Licence, or when elections take place, and notices from the electoral register are sent out. However, one must realise that public administration on all levels serve a much broader variety of purposes.

Duties and responsibilities of administrative units are legally defined - some are even included in constitutions, whilst others, for more practical reasons are 'only' included in laws and by-laws. Currently, tasks and responsibilities of administrative units include providing education, healthcare services, sanitation (including urban sanitation and waste management), provision of basic utilities, managing documentation relating to private individuals, businesses and properties, and not least environmental and natural protection and sustainability services. This, however, is by no means a complete list. It must be realised, though, that administration is a key actor in the transition to sustainable development.

These duties are assigned to different levels of administration from country to country. Fundamentally, each state intends to define the levels of execution based on socio-economic, geographic and practical factors. Through a longer or shorter process of trial and error, an optimal (or quasi-optimal) level of execution may be found. However, as demands for administrative services change, supply must follow, or inadequacies - externalities - and waste will result. Moreover, as some of the services that need to be provided are capital-intensive, they may not be economically efficient under a certain threshold. These factors ought to be accounted for in lawmaking, by carefully and sensibly choosing the levels of execution. A number of legal systems in Europe are plagued with an inherent rigidness of public administration, where some fundamental values and constructs are fixed in national constitutions, and have remained there for even as long as centuries.

As the European Union strives for providing quality services for all its citizens across the Union, it may become apparent that in some cases it is the administrative system itself that may cause hindrances in achieving these goals. As newer services are expected to be provided, the administration is supposed to follow suit and carry out changes. In a significant number of cases, the European Union itself is providing aid for the improvement of services. Convergence, cohesion and harmonisation are a mutual driving force behind administrative reforms, but their success greatly depends on the willingness of the individual member state to implement profound - and sometimes even painful - measures. Indeed, whether a member state decides to proceed with administrative reforms or not, will have an impact on its efforts in becoming sustainable. As the lowest levels of administration play a particularly important role in efforts towards sustainable development, all and any changes on this level ought to consider their direct impacts on society, the economy and the environment [9].

In order to see what the situation is across Europe, let's now look at the most important aspects of Europe's administrative systems.

\section{The main features of Europe's administration}

If we look at a map of the 27-member European Union, we are taking a glance at a very diverse continent indeed. A geopolitical map will reflect both century-old traditions as well as turbulent changes. State borders have disappeared and reappeared, and then disappeared again, sometimes a number of times in a lifetime. Lower-level administrative divisions have changed to reflect newly established borders. Let us just think of the changes profoundly affecting the map of Europe after World War One, when a number of states have implemented new or novel solutions. Among other things, this event shaped the currently existing county system that can be found in Hungary even today. Some of the changes would be even more drastic in some countries. If we look at Czechoslovakia or Yugoslavia, both states existed as united, sovereign countries, and then, in a brief period in historical terms, both fell apart. Whether these changes were voluntary or involuntary, we shall not look at now, but we must look at how they have affected the lives of the people residing there.

During the course of much of their history, administrative divisions within European states have remained fairly constant. Even today, when most of these states are now members of the European Union, traces and outlines of age-old divisions can still be found. A different trend is also ever more apparent, which points towards the review and restructuring of administrative systems, mostly because of the European harmonisation processes. Even though nearly every single member state had to proceed with reforms, the extent of these varied greatly.

A similar diversity is apparent on the level of local governments. In terms of size, we can see local governments which are tiny, as well as significantly larger ones. Rationality can be found behind all of them, whatever the size. Administrative divisions may have remained virtually unchanged for centuries, but the post-World War Two era of Pax Europaea, along with the rapid technological development have permitted these divisions to be reconsidered.

Significant differences can be seen between areas and regions of the European Union, both in environmental-natural, societal and economic terms. As a supranational entity and potential future state, it is the Union's duty to provide its citizens to live under better conditions considering all three terms. Although it is rarely pronounced, any effort to break down differences between areas is anchored in sustainable development. Indeed, the integration of sustainable development is a declared goal of the whole European Union [6].

Development aid and investment offered by the European Union can be a significant moving force in the life and development of a region, provided that some critical elements are 
present in the first place. Without these, success cannot be guaranteed. It is therefore the task of the European Union to combat differences between areas through its regional development policy. However, to ensure this tool functions efficiently and fairly, administrative subdivisions must be as comparable as possible. Essentially the need for the creation of a uniform statistical scheme was recognised [21].

\section{Nomenclature d'Unités Territoriales Statistiques}

As early as the 1970s, the European Communities had to face a serious problem: it had to make sure large differences within its territory would be reduced, and it had to be ensured that the appropriate regions would benefit from any subsidies. But to find which areas are truly in need of subsidies, a scheme enabling comparison must be implemented [20].

While European integration progressed, statistical information-gathering became a more pressing issue. Problems with comparing territories have become as early as the 1970s, when Ireland appeared to be the "odd one out" of the rest of the Community. Therefore, it was to receive aid to close the gaps, but just how much, that was not so easy to decide. The European Commission has passed legislation about a system of statistical units, which was to be called Nomenclature d'Unités Territoriales Statistiques, which became more widely known by its acronym NUTS. Oddly, its actual use in practice only began in 2003, prior to that its use was mainly based upon a 'Gentlemen's Agreement' [20].

The NUTS-classification is based on existing administrative structures, and the legislation does not provide for the realignment of administrative units for the sake of NUTS comparability. However, should states choose to reform their internal administration, they remain free to do so. As an outline, units should be comparable in size in terms of population. Furthermore, in all cases, the statistical divisions are to be there to respect the "actual political, administrative and institutional situation.” Additionally, “[n]on-administrative units must reflect economic, social, historical, cultural, geographical or environmental circumstances" [19].

Fundamentally, the Regulation establishes a three-tier system of statistical units, with the provisions of further subdivisions on the lowest level (NUTS-3). However, existing administrative units cannot be split to reflect new NUTS-units, as this would inhibit statistical comparability. Units can, however, be grouped to form NUTS units. The Regulation sets clear guidelines for the size of statistical units, which are flexible enough to allow for local variations, yet remain comparable in size. A particularity of the scheme is that directly no geographical dimensions are fixed, rather they are implied. The main clustering principles are defined through geographic, socio-economic, historical, cultural and environmental aspects which are supposed to be considered.

As mentioned previously, the NUTS classification scheme was created to facilitate the comparison of territorial units, whilst leaving previously existing units intact. But what hap- pens if the reorganisation of the units becomes desirable, or even inevitable?

The Regulation has provisions for the re-definition of NUTS units, a sensitive area by all accounts. Firstly, for a long-term dynamic analysis, statistical data must be stable and consistent. To produce analyses spanning decades or centuries, the basis of investigation must remain unchanged, implying a great degree of rigidness in statistical units.

On the other hand, statistical investigations are carried out to offer information about a given area, so therefore statistical units must dynamically follow the changes in delimitations of territorial units. This is particularly important as this regulation does not provide for statistical units under NUTS-3 level. Any state may recognise a need for the rationalisation of its internal administrative system, and nowadays such a trend is recognisable in a number of states. The Regulation does not prohibit the modification of NUTS units, provided that some criteria are met. Naturally, the definition of administrative units is an internal affair of the state, and as these will have implications to NUTS units too, the state is required to report the changes to the European Commission. The Regulation only states that any changes in the NUTS units may only be done so that it enables greater comparability, in other words, the units are to get closer to the average, rather than shift away from that.

The main issue with NUTS units originates in the problem that not all NUTS units are existing administrative units. A need for profound coordination puts strain on administration, as planning as well as reporting is done on a level that they are not fully compliant with [8].

NUTS-4 and NUTS-5 units were brought to existence in the original form of the Regulation, but were later dropped in favour of two levels of Local Administrative Units, LAU-1 and LAU-2 [18].

The fundamental problem with local administrative units is that no coherent and universal definition could be formulated so far. Whereas stringent regulations exist for defining the "top four" levels of territorial units, even vague definitions are almost completely absent for the lowest ones. The only - rather loose - definition states that no LAU may exceed the lower bound of a NUTS-3 unit. It is therefore foreseeable that the European Commission takes to defining the appropriate limits [14].

If we consider the variety in European administration, the picture is as diverse as the Union itself. In some states, the top-level local administrative unit corresponds to NUTS-3 units. If we take a look at naming conventions, it is evident that the equivalents of commune and arrondissement are becoming yet more prevalent. There is, however, a difference between the levels of these units; in a few states communes are LAU-1 units, while in a number of other states they are LAU-2 units. In the case of arrondissements, where they exist, they are predominantly on LAU-1 level, except for two instances - namely Denmark and Portugal - where they fall below the equivalent of a commune. One must note that a commune across the Union will denote a 
municipality, a larger administrative unit than, for example, in France.

The diversity found in public administration will definitely have a direct and indirect influence on residents. We may suppose that the differences between administrative units do not simply materialise in name, but rather a difference will be apparent in both size, functions, legal status and assigned tasks. Therefore, we need to find a method which will enable the comparability of these units.

\section{Local administration across the European Union}

We have already identified the level of diversity present in public administration across the Union, and it is easy to imagine how much this can complicate efficient working. Nevertheless, we need to find a way to compare existing systems in order to describe a desirable and optimal form of administrative units.

The following table shows a possible means of comparison. The table contains data about the individual member states and their Local Administrative Units. Data describing geography and demographics have also been included, which will be used to create indicators, thus enabling comparison. As data is only available on member-state level, differences within the state will remain oblivious, and no estimation of distribution can be included in the table.

Indicators have been defined for both levels of local administrative units, and using these, we can get a picture reflecting the spatial and demographic aspects of territorial administration. As we can see from the table, the population of over half a billion people share some 4.5 million square kilometres between them. On average, this means just over 112 people for each square kilometre, nearly matched by Slovakia and Portugal.

If we now consider the number of units in the Union, it becomes apparent that some 8023 LAU-1 units exist, an average of 309 and a median of just 69 per member state, indicating that most states have only comparatively few LAU-1 units, but also that some member states have an extraordinarily high number of such units. The difference between the two extremes of the scale can be found between Cyprus and France, where the difference in the number of units is five-hundredfold, whereas the difference in population is only 150 -fold, and the territorial difference is 200-fold. On average, there are 57384 inhabitants per LAU-1 unit, but the median shows 79419 people, which also indicates that most member states have a lot of people living in each LAU-1 unit, and a handful has far fewer inhabitants per unit. In fact, only eight states have lower-than-average population densities in their administrative units, all the others are well over this figure. If we look at the surface area of these administrative units, the average falls to 510 square kilometres, and a median at 924 square kilometres. These numbers reaffirm that in most member states administrative units are sizeable, but in a smaller proportion of states a strong fragmentation is apparent. The two extremes can be found between Malta and Sweden, with the tiny island state fitting inside the expansive Nordic country some four thousand times, and a single Swedish administrative unit being sixty-eight times the size of the whole of Malta. Even by filtering out these two extremes and focussing on the quartiles, we are confronted with a six-fold difference between Bulgaria and Austria.

Let us now consider the second level of local administration. Across the Union, we can encounter 121601 LAU-2 units, averaging 4504 per member state. Malta boasts with a mere 68 local units, but the most striking figure is that of France: 36683 French communes make out almost one-third of all European LAU-2 units. If we look at the quartiles again, the Netherlands have only 443 LAU-2 units, whilst the Czech Republic has 6 249. This fifteen-fold difference is unjustified by Czechia's size, so the fragmentation is quite obvious. Considering the population for each unit, the average is 4121 , and the median is 5682 per unit across the Union. These figures reflect that a great number of member states have small populations per administrative unit, with but a few housing larger populations. It is also important to note that the 1.3-times difference between the median and the upper quartile indicates that there is a particularly large number of small-population units across the Union, including France's tiny settlements. When looking at size, the difference is still striking: Malta's average LAU-2 is well under $5 \mathrm{~km}^{2}$ in size, while Sweden's corresponding units average over $1500 \mathrm{~km}^{2}$. Other data also back up a claim that the Union is "diverse in diversity", meaning that the differences in administrative structure also show great differences.

\section{Administrative diversity - blessing or curse?}

Let us now continue the analysis from a social, economic, environmental, political and historical point of view. It is to be expected that this already heterogeneous picture becomes even more diverse. Instead of analysing each member state in turn, we shall proceed by groups of states, clarifying the clustering factor each time.

\subsection{Scandinavia}

As we can see from the figures, Scandinavia hosts a comparatively small number of extensive administrative units. With a population of only 20 million people, it has a surface area of over $800000 \mathrm{~km}^{2}$. Sweden and Denmark have been dominating this region for much of its history, with the traits of Swedish administration reflected in Denmark and Sweden (and even Norway and Iceland, both currently outside the Union). The last phase of reforms was particularly profound: regions, counties and communes were formed in the early 21 st Century, scrapping the functions of all other constructs. Denmark followed a slightly different path, though, with former LAU-2 units remaining formally intact, but its role was reduced to essentially null [13]. 
Tab. 1. Local Administrative Units in EU members. Source: self-made and updated based on data from Annex to 105/2007/EC [5]

\begin{tabular}{|c|c|c|c|c|c|c|c|c|c|}
\hline \multirow{2}{*}{$\begin{array}{l}\text { Member } \\
\text { state }\end{array}$} & \multirow{2}{*}{$\begin{array}{l}\text { population } \\
\text { [capita] }\end{array}$} & \multirow{2}{*}{$\begin{array}{l}\text { area } \\
{\left[\mathrm{km}^{2}\right]}\end{array}$} & \multirow{2}{*}{$\begin{array}{l}\text { Pop. den- } \\
\text { sity } \\
{[\text { cap/km²] }}\end{array}$} & \multicolumn{3}{|c|}{ LAU-1 } & \multicolumn{3}{|c|}{ LAU-2 } \\
\hline & & & & $\begin{array}{l}\text { no. of } \\
\text { units }\end{array}$ & $\begin{array}{l}\text { mean pop. } \\
\text { [capita] }\end{array}$ & $\begin{array}{l}\text { mean area } \\
{\left[\mathrm{km}^{2}\right]}\end{array}$ & no. of units & $\begin{array}{l}\text { mean pop. } \\
\text { [capita] }\end{array}$ & $\begin{array}{l}\text { mean } \\
\text { area } \\
{\left[\mathbf{k m}^{2}\right]}\end{array}$ \\
\hline Austria & 8372930 & 83871 & 99.83 & 35 & 239227 & 2396.31 & 2357 & 3552 & 35.58 \\
\hline Belgium & 10827512 & 30528 & 354.67 & 44 & 246080 & 693.82 & 589 & 18383 & 51.83 \\
\hline Bulgaria & 7576751 & 110910 & 68.31 & 264 & 28700 & 420.11 & 5329 & 1422 & 20.81 \\
\hline Cyprus & 801851 & 9251 & 86.68 & 6 & 133642 & 1541.83 & 613 & 1308 & 15.09 \\
\hline Czech & 10512397 & 78866 & 133.29 & 77 & 136525 & 1024.23 & 6249 & 1682 & 12.62 \\
\hline \multicolumn{10}{|l|}{ Republic } \\
\hline Denmark & 5547088 & 43094 & 128.72 & 99 & 56031 & 435.29 & 2148 & 2582 & 20.06 \\
\hline United & 62041708 & 244820 & 253.42 & 443 & 140049 & 552.64 & 10664 & 5818 & 22.96 \\
\hline \multicolumn{10}{|l|}{ Kingdom } \\
\hline Estonia & 1340274 & 45226 & 29.64 & 15 & 89352 & 3015.07 & 227 & 5904 & 199.23 \\
\hline Finland & 5350475 & 338145 & 15.82 & 77 & 69487 & 4391.49 & 416 & 12862 & 812.85 \\
\hline France & 64709480 & 674843 & 95.89 & 3787 & 17087 & 178.20 & 36683 & 1764 & 18.40 \\
\hline Greece & 11125179 & 131990 & 84.29 & 325 & 34232 & 406.12 & 6130 & 1815 & 21.53 \\
\hline Netherlands & 16576800 & 41526 & 399.19 & 40 & 414420 & 1038.15 & 443 & 37419 & 93.74 \\
\hline Ireland & 4450878 & 70273 & 63.34 & 34 & 130908 & 2066.85 & 3441 & 1293 & 20.42 \\
\hline Poland & 38163895 & 312683 & 122.05 & 379 & 100696 & 825.02 & 2478 & 15401 & 126.18 \\
\hline Latvia & 2248961 & 64589 & 34.82 & 33 & 68150 & 1957.24 & 527 & 4267 & 122.56 \\
\hline Lithuania & 3329227 & 65303 & 50.98 & 60 & 55487 & 1088.38 & 518 & 6427 & 126.07 \\
\hline Luxembourg & 502207 & 2586 & 194.20 & - & - & - & 116 & 4329 & 22.29 \\
\hline Hungary & 10013628 & 93030 & 107.64 & 174 & 57549 & 534.65 & 3152 & 3177 & 29.51 \\
\hline Malta & 416333 & 316 & 1317.51 & 6 & 69389 & 52.67 & 68 & 6123 & 4.65 \\
\hline Germany & 81757595 & 357050 & 228.98 & 1457 & 56114 & 245.06 & 12379 & 6605 & 28.84 \\
\hline Italy & 60397353 & 301318 & 200.44 & 107 & 564461 & 2816.06 & 8101 & 7456 & 37.20 \\
\hline Portugal & 10636888 & 92391 & 115.13 & 308 & 34535 & 299.97 & 4260 & 2497 & 21.69 \\
\hline Romania & 21466174 & 238391 & 90.05 & 42 & 511099 & 5675.98 & 3174 & 6763 & 75.11 \\
\hline Spain & 46087170 & 506030 & 91.08 & 59 & 781138 & 8576.78 & 8111 & 5682 & 62.39 \\
\hline Sweden & 9347899 & 449964 & 20.77 & 21 & 445138 & 21426.86 & 290 & 32234 & 1551.60 \\
\hline Slovakia & 5424057 & 49037 & 110.61 & 79 & 68659 & 620.72 & 2928 & 1852 & 16.75 \\
\hline Slovenia & 2054119 & 20273 & 101.32 & 58 & 35416 & 349.53 & 210 & 9782 & 96.54 \\
\hline European & 501078829 & 4456304 & 112.44 & 8023 & 62455 & 555.44 & 121601 & 4121 & 36.65 \\
\hline \multicolumn{10}{|l|}{ Union } \\
\hline mean & 18558475 & 165048 & 112.44 & 309 & 60142 & 537.84 & 4504 & 4121 & 36.65 \\
\hline median & 9347899 & 83871 & 101.32 & 69 & 79419 & 924.63 & 2478 & 5682 & 29.51 \\
\hline
\end{tabular}

\subsection{The Baltic States}

The three Baltic states took a very peculiar course between 1990 and 2010. In but a decade and a half, they have moved from the Soviet Union to the European Union, a change evident in their public administration too. All three former Soviet republics were quick to stress their independence with speedy administrative reforms, and they engaged in a second wave of reforms around their accession to the EU. In both cases, a very obvious motif was to show their difference first, and their sameness later on. All three states took radical steps towards rationalising their public administration by either reducing or withdrawing powers from local units.

\subsection{The Benelux}

The history of the Benelux Countries goes back centuries, but in its present form, the cooperation between them was started in
1955. What is rather surprising in this case is the time it took for this particular cooperation to begin, considering the fact that for most of their history, these states were usually within the same country. The most profound change in administration was when Belgium ditched its former unitary structure and decided to become federalised. The other two states have done little to change, save for the serious reduction in the numbers of local administrative units, with the formation of municipalities [13].

\subsection{The British Isles}

The countries of the British Isles were always keen to maintain their distance from the rest of the continent, fuelled partly by eccentricity and enmity. Two states remain in the place where the centre of the British Empire once stood: the United Kingdom and the Republic of Ireland. Whilst administratively the two states are similar, there are significant differences both out- 
side, but also inside the states, particularly within the United Kingdom. Administratively, England and Wales are the most akin, Scotland and Northern Ireland are more or less different. Northern Ireland is particularly strange, because it needs to be different from both the rest of the UK, but also from Ireland. In fact, it is so different, that its administration resembles Slovakia and the Czech Republic, rather than the UK.

\subsection{Western Europe}

The next region to look at is Western Europe, but as we have treated the Benelux, we can now exclude that group, and as Switzerland is not part of the EU, we will not mention it in this section. France's administrative divisions have their roots in the French Revolution, with départements replacing former provinces, and arrondissements and communes providing an intermediary step. As mentioned before the large number of communes in France poses a real problem, and while it could prove to be a model country in regionalisation, its problems with administration must be realised. Germany and Austria took a different path altogether. After the Second World War - and mostly through American pressure - both states were reorganised as federal states, thus reducing the chance of another war altogether. Evidently this structure has suited both states well, and have remained under the same structure ever since. Both states have a large number of LAU-2 units, but not in the scale of France [16].

\subsection{The European South and Mediterranean}

Europe's Mediterranean coast is shared by six EU members: Greece, Italy, Spain and Portugal - this latter one is actually an Atlantic state, but it resembles most Mediterranean states, so it can be included here - and Cyprus and Malta. A number of states have a shared or similar history, so it is worthwhile to treat them together. Historically, there have been close links between Spain and Portugal, Italy and Malta, as well as Greece and Cyprus. After the Carnation Revolution, Portugal was divided into 18 districts and 308 communities, a system very similar to that in the Republic of Hungary. Spain was administered under a traditionalistic regime of Francisco Franco, dominated by Castile and León, which was then replaced by a democratic monarchy. With the democratic constitution of 1978, 17 autonomous communities and two autonomous cities were created, grouped into exactly 50 provinces.

Italy is administratively similar to Spain and France: 20 regions, 107 provinces and over 8000 communes constitute this state. All three of these states are considered to be regionalised, but Spain and Italy are asymmetrically regionalised, meaning that certain regions have a wider autonomy than others. The reasons for such an asymmetry can be found in the desire of survival of the state. In a contrary situation, some regions may pursue a path of secession from the state. Spain is frequently billed as a "state of autonomies", since the state has decentralised nearly all its functions, effectively rendering it a de facto federal state, even though the Spanish constitution states that its unity is inviolable. Essentially, Spain resembles Germany and Belgium more than any other European state.

Greece has recently joined the group of states with a modernised public administration, a feat certainly commendable. In what turned out to be a two-phase reform spanning a decade and a half, Greece has clustered its 6130 settlements into just 325 communities, it has eliminated its 54 prefectures, empowered its regions previously in existence virtually 'on paper only' with an extensive autonomy [7, 15] Cyprus and Malta's administrative regimes reflect the tiny size of the islands. Malta consists of 68 councils, and Cyprus of 613 communities, which are clearly very small, so fragmentation on these islands is extraordinary [17].

\subsection{Central Europe and the Balkans}

Central Europe and the Balkans have seen two decades of profound changes, surpassed only by the Baltic states. Several of the previously existing states have split to form several newer states, a number of which have already joined the EU, with the rest seeking membership. The amount of administrative changes depended on how these states lived through the transitions. Poland established regions which echo the country's former structure. They have also established districts on LAU-1 and communes on LAU-2.

The two successors of Czechoslovakia have achieved commendable results in administrative reforms. They took a rather proactive strategy, essentially following NUTS guidelines and carried out administrative reforms. From the former Yugoslav republics, only Slovenia is a member of the EU, with Croatia and Macedonia both holding candidacies for over half a decade. Serbia has also submitted its application to join in 2009, and if the Papandreu-plan is successful, the country stands a chance at joining in 2014, on the $100^{\text {th }}$ anniversary of World War One. The largest part of former Yugoslavia has therefore expressed its desire to build its future within the EU. Croatia has reestablished its former county system, and has introduced regions after its application of accession. Serbia has carried out a truly remarkable and comprehensive administrative reform, by creating autonomous regions within the country, and under this level there are communes and cities, eliminating a number of redundant intermediary levels. Such an approach could be beneficial to Hungary too.

Romania's bloody revolution has also provoked some administrative changes. As it has been the practice in Romania's history, they took France and Italy as models for the reform. The new constitution has joined several settlements into communes, with counties being the other constitutional level of administration. These have remained static for years, and only with European accession afoot was the option of reforming counties and introducing regions considered [1]. Several plans have appeared, with varying radicalism, and even considering the introduction of cantons, but the outcome is yet to be seen [2]. 
Only two states from this region have not been treated yet: Hungary and Bulgaria. These countries have a lot in common, a number of parallels and similarities in history and society. This is also true for the post- 1990 period as well. Bulgaria took to reforming its administration twice during the last three decades. First in 1987, territories, effectively the equivalents of regions were created [10]. However, it can be reasoned that these decentralisations were actually centralisations, as the powers from the previous districts (okrugi) were assumed by much larger entities (oblasti). This was a late and futile attempt to preserve singleparty state power. Later on, these territories were scrapped, and the previous system of districts was reinstated, but units were called territories (oblasti) instead. The great difference between the two countries is to be found in the number of local units. Bulgaria has reduced this number to 260 by 1999, whereas Hungary is still plagued with a number in excess of 3000 .

Hungary has been the least eager to carry out any profound reforms; in fact, even the most necessary changes were ignored. After the changes of 1989, the first freely elected government reduced the power of the counties, which were infamously strong political bases. Some of the roles were assumed by the newly formed municipalities (one for each settlement), and others by the state itself. Municipalities were given extensive autonomy, further adding to the fragmentation of the country. With the accession to the EU afoot, the NUTS-2 and (then) NUTS-4 regions needed to be defined. With the reluctance to carry out administrative changes, some territories were statistically disadvantaged, which could have been easily avoided [18].

Let us not forget that most countries in this part of Europe are - or in some cases, were - heavily dependent on agriculture, so the changes affecting rural communities in particular, will play an important role in the future of these territories. Due to unfavourable changes in recent decades, country life has become synonymous with undereducation, underemployment, infrastructural deficiencies, poor quality and expensive community services, and the lack of a clear future vision and vulnerability [3].

\section{Reasons for (avoiding) administrative reform}

As this has been discussed in previous sections, several reasons may stand behind reforms (or the complete lack thereof). A number of states decided to reform to reaffirm their belonging to or alienation from something. The three Baltic States wished to demonstrate that they are taking a completely different route from the Soviet Union. Latvia even went so far that they have reduced the administration to a single level. Post-Yugoslav states took a similar path, with Slovenia, Croatia, and perhaps surprisingly, even Serbia taking strides towards demonstrating that it was no longer Yugoslavia.

In other countries, the lack of reforms could be traced back to political reasons. This phenomenon was true to the UK, France, Germany, Spain, Italy, Ireland, but even Hungary. A varying level of traditionalism is true to each of these countries, which also manifests itself in its political leadership. If this is coupled with demagogy, a festering political fruit promising certain votes hanging too low for politicians to ignore, the situation can only get worse. Of course, in countries with a developed political culture, this problem is less acute, but countries which have sawn the seeds of democracy more recently, this problem will be quite serious indeed. As reforms will affect day-to-day political game, politicians will be reluctant to take steps towards serious reform, as any such move can easily cost them their jobs. During Greece's battle for administrative reform, one could bear witness of just this [12]. Obviously, on the long run, each political side can be expected to make the same "benefits" and "disadvantages". The promise of an early political victory remains too tempting to ignore.

The situation on the British Isles is somewhat different: open and very theatrical political battles are fought, but changes were avoided because of traditionalism and a desire to keep a distance from the rest of the EU.

Belgium was more ready to take to reforms: tensions within the country were so high that by the 1960s they could not do anything else but reform. This has ended up in a 'near-Cold War situation' internally, and the relationship between parts of the country is still more hostile than friendly, which is reflected in the successively collapsing federal governments of the country.

We have not talked about all member states here, but we can be certain that besides the intention to improve, the urge for political success is also present. Some states, however, do seem to show due diligence, but nevertheless, we shall have to confront short-term political interests in the future too.

\section{Administrative systems serving sustainability}

The role that could be assumed by local and micro-regional entities in the transition to sustainable development were first highlighted in the admittedly short Chapter 28 of Agenda 21, signed in Rio de Janeiro almost two decades ago. This chapter may have been limited in length, but certainly not in impact, as this document describes the tasks, duties and responsibilities of local authorities in local programmes aimed at sustainable development [23]. As a large number of challenges have their roots in the local and micro-regional level of administration, the cooperation of local authorities in sustainable development initiatives is desirable, as local authorities are responsible for the maintenance of the economic, social and environmental infrastructure on the level closest to citizens [4]. During the course of the last two decades, local sustainable development initiatives have sprouted, backed up by some well-established organisations such as ICLEI - Local Governments for Sustainability, currently the world's most renowned platform for information exchange in local sustainability. As Local Agendas require a planning process - and therefore need to be periodically evaluated and updated - indicators need to be devised. To support this, the so-called "Bellagio Principles for Assessment" have been created, offering guideline principles and a framework for 
feedback on local sustainability initiatives [23].

The elements of Agenda 21 and derivative principles have since found their way into several levels of national and European policy. These are also reflected in the European Union's Sustainable Development Strategy, which highlights the inclusion of these said principles of sustainable development in all policies.

The three main aspects of sustainable development are familiar to most people: environment, society and economy. All three aspects are interdependent, and none may be excluded from the analyses of sustainable development. An alternative interpretation includes an additional fourth aspect, the political dimension [24]. To serve the requirements of sustainable development, administration must be taken into account and adjusted to incorporate the principles of sustainable development in all its policies.

The properties of administrative units fundamentally outline if a territory can become sustainable or not. Five criteria must be considered here:

- the population of the administrative unit,

- the geographical size of the unit,

- the wealth (or poverty) in resources, including environmental source and sink functions,

- the location (situation) of the administrative unit,

- legally defined roles (duties, responsibilities, scope of authority, powers), in other words, the political weight of the unit [22].

Clearly, all these factors will be interconnected again, as the population will determine the demand for resources, the geographical size and wealth will indicate supply, and this will be corrected by factors of location and role of the unit. It is obvious that the smaller a population is with a greater wealth and larger size; the "easier" it will be to become sustainable. Aspects of agglomeration and clustering also play an important role, as some infrastructural investments are only economically feasible over a certain size and population. The wealth or poverty in resources and environmental services of the area is critical, as this is an indicator of environmental sensitivity. Even if two areas are virtually the same, differences in location (and thus climate) will have serious influences on the area. Finally one must also consider the roles and political weight of the administrative unit. In an optimal scenario, a unit will have sufficient autonomy to take decisions which would enable it to become or remain sustainable. If the state is more centralised, local information will be lost and particularities will be disregarded, and the unit may be depleted rapidly. This is particularly true to non-democratic or democratising countries. On the other hand, if a state is decentralised and local units are more powerful, they may be prone to overusing or even wasting resources. This way the local level becomes disproportionately powerful, and political game play will plague decisions, with the necessity for a sufficiently holistic approach lost completely. A doctrine seems to have become accepted which states that the road to global sustainability leads through local activity. This doctrine may only be true if local authorities do not forget their global responsibilities. If an administrative unit is disproportionately powerful, it may be prone to waste, but paradoxically it may also try to pretend it is too small to have an effect on global processes. We can therefore say that adhering to the principle of subsidiarity is essential, but solely if control from both superior and inferior administrative units remain. The desirable relationship between the levels is best described as of mutual control and partnership.

One of the most important principles in the EU is the principle of subsidiarity, or the delegation of tasks to the lowest possible competent unit, which is still capable of carrying them out efficiently and sufficiently.

A number of European states have constitutions where the most important level of administration is also the lowest one, entrusting it with a high level of autonomy, with lots of duties and responsibilities, but also a lot of credit is to be taken for anything that gets done. However, if these units are too small, carrying out some tasks becomes unnecessarily costly, sometimes unaffordable. A number of local authorities have recognised the opportunity in sharing duties, which permits a saving, realised through economies of scale. So, in reality, the principle of subsidiarity does not always mean decentralisation.

Historically, many European states were centralised, and it took national governments less or more time to give in to decentralisation. States that have overthrown dictatorial regimes would carry out changes quickly, but not always efficiently. Indeed, several cases of over-decentralisation are present here, which, for the sake of sustainable development and with fully adhering to the principle of subsidiarity, must be corrected. Of course, there is no single universal model for allocating duties and responsibilities, and the process is painstaking, painful and it takes a lot of trial and error. Decision-makers at all levels must realise that any such changes are not initiated for their annoyance, but ideally, for the sake of sustainability.

\section{European trends in administrative reforms}

As mentioned in the previous section, a number of European states are organised "bottom-up", i.e. from the smallest to the largest administrative units. This is the case in Greece, France, and even in Hungary. The following sections will investigate the changes that have taken place in some parts of Europe.

\subsection{Communes and regionalism in France}

The history of the communes of France goes back to the French Revolution, when the republican ideas fuelled administrative reorganisation. Grouping town wards into communes was no big challenge, but rural areas were more difficult to consolidate. As a second level, départements were created, centred on key cities and named after particular geographical features; 
this level was there to make public administration a more practical duty.

As the Industrial Revolution swept across Europe, technological advances sped up the pace of life - and information. Whereas in the 18th Century, the speed of information was the pace of a horse at best, by the 19th Century, with the advent of telegraphy and telephony, information propagated at incredible speeds. By the 20th Century, communication has reached the speed of light, and as travel and communication became widely available, 18th Century principles for organising administration have lost their appeal. By 1982, regions were introduced in France, gaining an increasing autonomy over time.

Let us take a glance back at the settlements. At the end of the 19th Century, when the first utility networks were installed, communes faced a problem. Firstly, they were required to provide utilities to their citizens, but installation of such facilities would burden them with enormous costs. Firstly, a law from 1890 permitted that a single-purpose grouping of communes took over some tasks from the communes [11]. With improving job prospects in towns, thousands left villages behind and took to the ever-growing cities, forming increasingly larger agglomerations with all their positive and negative aspects. PostIndustrial Revolution rural population suffered great losses in numbers and homogeneity, and rural areas left empty struggled to keep to their legally defined duties, and to provide even the most basic utilities.

The longer these problems were left to simmer, the more radical solutions were required. The first considerable breakthrough was in 1999, when the Chèvenement law was passed, allowing communities of communes to be formed. Even though most local councils have recognised the benefits of these communities, far less than $100 \%$ of councils have joined such groupings. Currently, they are mostly there to attempt a certain level of coordination between communes to improve services, particularly in the utilities sector. This, however, fails to tackle the enormous costs that arise from the maintenance of such a large number of units on so many different levels of administration [11]. The fact remains that a third of all European localities can be found in France.

Such a fragmentation of territory is very dangerous from a sustainability point of view as well. It is quite obvious that the holistic criterion will be violated, which becomes particularly alarming if we consider the fact that the duties and powers of such local councils are very extensive.

\subsection{Municipalities in Germany, Italy and the Netherlands}

A number of European states took proactive steps to prevent further problems arising from fragmentation, and took steps towards careening localities into larger clusters. A large scale reform was carried out in the Federal Republic of Germany in the 1970s, and as a result, the number of municipalities was reduced to a third, though still a large number by all accounts. A similar action was attempted in Italy at the time, without great success.
Traditionalistic feelings were strong in both countries, but the changes did manage to streamline the administration.

\subsection{Nordic regions, Baltic communities}

Groundbreaking changes have been realised in Scandinavia, the Baltics and parts of Yugoslavia. Scandinavia scrapped its provinces and territories, and introduced new, better regulated units of administration. Regions, counties and communal municipalities were introduced in Sweden; this latter unit was formed by establishing municipalities from previous settlements. Even though the settlements still exist in name and identity, they have been stripped of all their functions. Denmark was even more radical, as they have scrapped all levels between regions and communes. Furthermore, Denmark initiated a clustering of old settlements into communes of at least 20 000 inhabitants, a guideline number they did not follow if the groupings would have been irrational.

The Baltic States took a path similar to Scandinavia. Latvia scrapped all intermediary levels, and now boasts a one-level administrative system. The resultant units in all Baltic States are small compared to the EU average, but are comparatively large in terms of duties and responsibilities. Lithuania kept its intermediary administrative levels, but it has consolidated its localities into only 60 communal municipalities. Estonia remains the odd-one-out, with the most diverse administrative structure remaining there. A lamentable fact remains that neither of these states has truly implemented regions beyond the necessary planning stages.

From the above, and bearing in mind the requirements laid out previously, Scandinavia and the Baltics seem to have a great potential for the administrative system supporting sustainable development.

\subsection{Mediterranean autonomies}

Italy and Spain have taken strides towards regionalising their structures, a move hardly surprising if we consider that these were never truly unitary states. Demographic and cultural differences remained present throughout history, surfacing and culminating in conflicts at times. Both countries needed profound changes by the late 20th Century. The most important change in both countries was the creation of regional autonomies, essentially preventing a collapse of state. A problem remaining even today comes from the uneven - or asymmetric - autonomies present in these states, sparking tensions within the country. Nevertheless, this model seems to be working well, although both countries have a long way to go towards sustainability.

Greece was one of the last countries in Europe to carry out profound administrative changes. After several devastating decades, Greece has started to enjoy significant economic growth in the 1960s. A stable trend of growth began, but whenever this trend halted - whatever the reason may have been Greece suffered considerably. This was the case after the Dictatorship of the Colonels was overthrown, and this was also the 
case when Greece plummeted into economic meltdown during the sovereign debt crisis. As part of the plan for tackling the predicament, administrative reform was added to the austerity measures, aiming to save 1.8 billion euro annually, about halfa-percent of Greece's annual GDP.

The controversial scheme swept across Greece like a whirlwind, with thousands protesting against it. On the one hand, it would remove two levels from Greece's public administration, leaving 13 regions and 325 municipalities, on the other hand, it would affect 200000 employees, with an estimated 35000 laid off in the process. The changes are too recent to allow deductions to be made of its success. Nevertheless, as the scheme was made up of strategies that have already proved to be working well in other states, one may reasonably anticipate a success in Greece too.

\section{Summary}

We have looked at the administrative systems present in the European Union, comparing their similarities and contrasting the differences, and we tried to look at the reasons of this diversity. We have shown the particularities of NUTS, which could serve as a guideline for reforms in high-level administrative reforms. We have also looked at lower-level administrative units, often struggling to keep up with their legally defined duties. We have also looked at administrative reforms initiated during the last decades. We have also established a set of criteria to compare administrative systems.

Whilst Europe's administration remains colourful, some trends of convergence are emerging too. Several states have decided to re-think reforms previously carried out, and moving duties and responsibilities up or down between levels. Some states carried out large-scale changes, whilst others shied away and made do with more symbolic refinements. The differences are likely to be found in the political attitudes and the innovative will of the population - but also at the level of consciousness and concern about public spending.

Comparability is greatly facilitated by the NUTS system, but the lack of regulation on the lower levels may pose a problem. Clearly, the introduction of widespread changes on the lowest levels may be met with considerable resistance, especially if the changes are not communicated appropriately. Extraordinary care must be taken when taking local features into consideration, more so than at higher levels. When redefining local administrative units, historical, social, cultural and economic aspects must be taken into consideration, but not less so, aspects of sustainability and ecology must also be accounted for. It is probable that setting guideline dimensions may be difficult, but as we have seen in the case of Denmark, it can be implemented. In any case, sensitivity and sustainability assessments must be carried out prior to all and any changes.

A definite positive aspect would be that even profound changes would not be alien to most countries; indeed, those riding with the wave are going to be in an advantaged situation.
We cannot just pick an existing model and just apply it to all other countries. The strength of any model would have to arise from its preservation and support of local knowledge and interests. However, to facilitate convergence, administrative reforms ought to be sped up across Europe, and fundamental principles need be defined and applied. Nevertheless, the true success of any administrative reform may only be established by considering its contributions to the efforts towards a sustainable future for citizens.

\section{References}

1 Băcanu P M, Cum ar trebui sa arate harta redesenata a Romaniei? (How will one encounter Romania's redesigned map?), România Libera, 11 March 2010, available at http://www.romanialibera.ro/opinii/ interviuri/cum-ar-trebui-sa-arate-harta-redesenata-aromaniei-179771.html Accessed on 5 May, 2010.

2 _ Cum va arata harta Romaniei? (What will the map of Romania look like?), România Libera, 17 July, 2008.

3 Buday-Sántha A, A Magyar agrár-és vidékfejlesztés ellentmondásai, (The Contradictions of Agrarian and Rural Development in Hungary), Magyar Tudomány, (August 2009), 937-945.

4 Bulla M (ed.), Feladatok a XXI. századra, (Tasks for the 21 st Century), Föld Napja Alapítvány, Budapest, 1993.

5 Commission Regulation (EC) No 105/2007 of 1 February 2007 amending the annexes to Regulation (EC) No 1059/2003 of the European Parliament and of the Council on the establishment of a common classification of territorial units for statistics (NUTS), 2007. 2. 10, available at http://eur-lex.europa.eu/LexUriServ/LexUriServ. do?uri=0J:L:2007:039:0001:0037:HU:PDF Accessed on 2 May, 2010.

6 Communication from the Commission to the Council and the European Parliament on the review of the Sustainable Development Strategy - A platform for action, Brussels, 13 December 2005. COM (2005) 658 final.

7 Constitution of Greece, Hellenic Parliament, Athens, 2010, ISBN 978-960560-073-0.

8 Correspondence between the NUTS levels and the national administrative units, Eurostat, 2007, 2007, available at http://ec.europa.eu/ eurostat/ramon/nuts/introannex_regions_en.html Accessed on 1 May, 2010.

9 Csete M, A fenntarthatóság kistérségi vizsgálata, (Microregional Sustainability Assessments), Budapest, 2009. PhD Dissertation, Budapest University of Technology and Economics, Doctoral School of Economic Management Sciences.

10 Curtis G E (ed.), Bulgaria: A Country Study. Washington: GPO for the Library of Congress, 1992, available at http://countrystudies.us/ bulgaria/ Accessed on: 28 March, 2011.

11 Girardon J, L'intercommunalité. Éditions Ellipses, Paris, 2008, ISBN 9782-7298-3703-7.

12 Hübel E, Proteste gegen Verwaltungsreform „Kallikratis“ nehmen zu. Griechenland Zeitung, (Protests against administrative reform Kallikratis escalate), 25 May, 2010, available at http://www.griechenland.net/ news_details.php?siteid=9298 Accessed on: 26 March, 2011.

13 Illés I, Regionális gazdaságtan - Területfejlesztés (Regional Economics Spatial Development), Typotex, Budapest, 2008, ISBN 978-963-279-004-6.

14 Knors N, Lück D, The LAU2 Code - How to Analyse Regional Differences, available at http://www.jobmob-and-famlives.eu/papers/JFW_0701_Lueck_Knors.pdf Accessed on 4 May, 2010.

15 New Administrative and Decentralisation Structure - Callicrates Programme, Athens, 7 June, 2010. Execution order no. 3852/2010. Government Gazette (FEK) I.-87.

16 Personal consultations with Professor Michel Carmona of Paris IV - Sor- 
bonne University, Honoris Causa Doctor of the Budapest University of Technology and Economics. Conducted between 18-20 January, 2010.

17 Personal consultations with Professor Emeritus Stergios Babanassis of the University of the Aegean. Conducted between 10-11 December, 2010.

18 Personal consultations with Professor Iván Illés of the Budapest University of Technology and Economics and of the Hungarian Centre for Regional Studies. Conducted between 21-28 April, 2010.

19 Regulation (EC) No 1059/2003 of the European Parliament and of the Council of 26 May 2003 on the establishment of a common classifcation of territorial units for statistics (NUTS)., Vol. 154, 200306 21, available at http://eur-lex.europa.eu/LexUriServ/LexUriServ. do?uri=DD : 14:01:32003R1059:HU:PDF Accessed on 2 May, 2010.

20 Regulation (EEC) No 2052/88 of 24 June 1988 on the tasks of the Structural Funds and their effectiveness and on coordination of their activities between themselves and with the operations of the European Investment Bank and the other existing financial instruments., Vol. 185, 15 July, 1988, available at http://eur-lex.europa.eu/LexUriServ/ LexUriServ.do?uri=CELEX:31988R2052:EN:HTML Accessed on 1 May, 2010.

21 Szabó P, A NUTS rendszer ki- és átalakulása, (The Establishment and Transformation of the NUTS System), Comitatus, XV(8-9), (szept. 2005 aug.), 7-14.

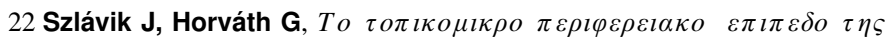
$\beta \iota \omega \sigma \imath \mu \tau \eta \tau \alpha \varsigma$ (Local and microregional levels of sustainability), Athens, 2011.

23 Szlávik J, Fenntartható környezet- és erôforrás-gazdálkodás, (Sustainable environmental and resource management), (2005), 245-246, 281-288.

24 UNESCO: Four Dimensions of Sustainable Development, available at http://wWw.unesco.org/education/tlsf/TLSF/theme_a/modQ4/ uncomQ4tQ1s03.htm Accessed on 27 March, 2011. 